\title{
A Human Ecological Model of Spirit at Work
}

\author{
VAL KINJERSKI \\ University of Alberta
}

\section{BERNA J. SKRYPNEK \\ University of Alberta}

\begin{abstract}
An empirically grounded, human ecological model of spirit at work specifying antecedent conditions and outcomes of spirit at work is presented. Spirit at work is a distinct state characterized by profound feelings of wellbeing, a belief that one is engaged in meaningful work, a connection to others and common purpose, a connection to something larger than self, and it has a transcendent nature. Four distinct paths to spirit at work are identified: always there, coming together, transformative event, and contextually sensitive. These paths are affected by individual factors (personality characteristics and personal actions) and contextual factors (organizational characteristics and transformative life events) that contribute to the experience of spirit at work. This model posits that personality, personal actions, and organizational characteristics are interconnected and operate to foster or impede an individual's spirit at work. Spirit at work appears to counteract disenchantment and disengagement at work and results in positive outcomes for employees, consumers, and organizations.
\end{abstract}

Keywords: Spirit at Work, Spirit at Work Model, Spirit at Work Theoretical Framework

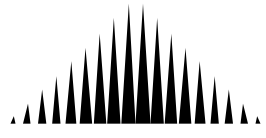

Reference: Kinjerski, V. \& Skrypnek, B.J. (2006) A human ecological model of spirit at work, Journal of Management, Spirituality \& Religion, 3(3), pp.232-239. 
$\mathrm{S}$ pirit at work, which involves profound feelings of wellbeing and a belief that one's work makes a contribution, is about finding meaning and fulfillment, beyond self, through work (Ashmos and Duchon, 2000; Kinjerski and Skrypnek, 2004; Milliman, Czaplewski, and Ferguson, 2003; Mitroff and Denton, 1999; Sheep, 2004). Whereas the link between spirituality and wellbeing is well known (George, Larson, Koenig, and McCullough, 2000; Paloutzian, Emmons, and Keortge, 2003), research is just beginning to support the view that the experience of spirit at work results in more fulfilling lives for individuals and positive outcomes for organizations (Fairholm, 1997; Groen, 2003; Kinjerski, 2004; Kinjerski and Skrypnek, 2006; Milliman, et al., 2003; Milliman, Ferguson, Trickett and Condemi, 1999; Mitroff and Denton, 1999; Moxley, 2000). As an antidote to disengagement and disenchantment at work, spirit at work has become a topic of great interest to employees and employers. Thus, a framework or model would assist the field to understand how spirit at work develops, to guide interventions to enhance spirit at work, and to foster empirical research.

We are proposing a human ecological model of spirit at work that is based primarily on the dissertation research of the first author as well as draws on our other research about spirit at work and is consistent with extant literature. The model is informed by: a qualitative study designed to define spirit at work (Kinjerski and Skrypnek, 2004); a qualitative study which identified how people come to experience spirit at work, the personality traits of individuals with high spirit at work, the personal behaviours and organizational conditions that foster spirit at work, and the perceived benefits of spirit at work (Kinjerski, 2004); a quantitative study where we surveyed over 300 people and resulted in a measure of spirit at work (Kinjerski and Skrypnek, 2006b), and a mixed-methods study investigating the effectiveness of a spirit at work intervention in the workplace (Kinjerski and Skrypnek, 2006).

\section{THE SPIRIT AT WORK MODEL: DEFINING PROPERTIES}

An empirically grounded human ecological model of spirit at work is presented in Figure 1. The elements that comprise the ecological model of spirit at work include: a conceptualization of spirit at work, personality characteristics, personal actions, and organizational factors. The interaction and interconnectedness among these components and the paths are illustrated. Finally, the benefits of spirit at work reflect the desired outputs of the model. A description of each of these components and their relationships follows.

\section{Conceptualization of Spirit at Work}

Spirit at work is a distinct experience characterized by cognitive features, interpersonal dimensions, spiritual presence, and mystical components (Kinjerski and Skrypnek, 2004; 2006b). Engaging work (cognitive) is characterized by profound feelings of well-being, a belief that one is engaged in meaningful work that has a higher purpose, and an awareness of alignment between one's values and beliefs and one's work. A sense of community (interpersonal) is portrayed by a feeling of connectedness to others and common purpose, whereas a spiritual connection characterized by a sense of connection to something larger than self. The fourth dimension, a mystical or unitive experience, is depicted by a positive state of energy or vitality and experiences of complete joy and bliss (Kinjerski and Skrypnek, 2006b).

\section{Integrated Personality}

Individuals who self report spirit at work share a distinctive personality (Kinjerski, 2004). Our research indicates that persons with spirit at work are well adjusted and exhibit a sense of inner harmony. They have positive energy, are conscientious, and tend to be open to possibilities. Compassionate and altruistic, persons with spirit at work are self-transcendent and spiritually inclined. These spiritually inclined individuals seek deeper meaning and a purpose beyond self and, as such, see work as an act of service. They are filled with gratitude and humility (Kinjerski, 2004). We call this collection of personality traits the "integrated self" personality profile because the essence of the spirit at work personality seems to be the integration of all these personality dimensions. We contend that personality is important in the creation of spirit at work and that the spiritual inclination dimension is the key personality dimension responsible for fostering spirit at work. 


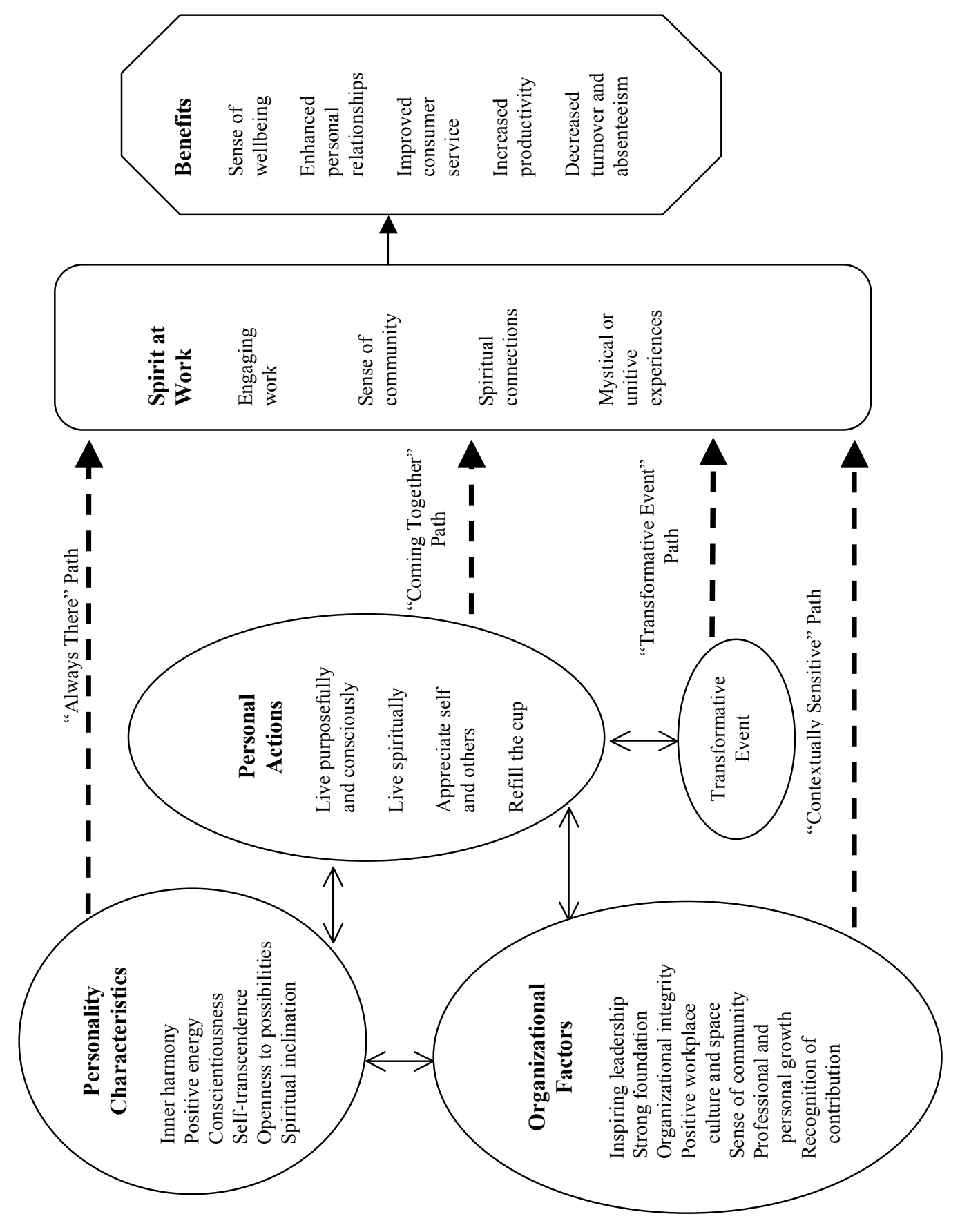

 
We were struck by the parallel of the integrated spirit at work personality profile with the Five Factor Model of personality (McCrae and Costa, 1999) with one important exception. What is left unexplained by the Five Factor Model of personality is the tendency of individuals with high spirit at work towards a spiritual inclination (Kinjerski, 2004). Spirituality seems to be the personality dimension that makes people's experience of spirit at work unique, suggesting that the inclination towards spirituality is what fosters individual transformation and spirit at work (Kinjerski, 2004). A strong connection with something larger than self, that quest for meaning, the sense of purpose beyond self, and the self-transcendent nature of those with a disposition towards spirit at work seems to make the difference. Not surprisingly, these traits are consistent with Piedmont's $(1999 ; 2001)$ notion of spirituality as a sixth facet of personality.

\section{Personal Actions}

Consistent with dominant views on personality (McCrae and Costa, 1999), it seems reasonable that personality interacts with personal actions to foster spirit at work. Following a constructivist view that people are co-creators of their life experiences (Denzin and Lincoln, 1998), these personal behaviours include taking responsibility and action for creating the kind of life which is desired, including one's work experience. In our research, persons with spirit at work report four actions which they perceive as contributing to their experience of spirit at work: (1) consciously living a life that is purposeful and meaningful; (2) working at cultivating and living a spiritual, value-based life; (3) recognizing one's own worth and the value of others and expressing appreciation for self and others; and (4) taking time to refill one's cup by pursuing that which is intrinsically rewarding and by engaging in self-care (Kinjerski, 2004).

These actions fit with a notion that we call "conscious intention" (Kinjerski, 2004). Being mindful about how one lives one's life and choosing to live with purpose and meaning is the essence of conscious intention. We view conscious intention as a critical factor in the creation of spirit at work because it reflects one's thoughts, values, feelings, actions, and ultimately, the choices one makes.

\section{Organizational Factors}

Personality and personal actions that contribute to spirit at work operate in an organizational context. Thus, it is not surprising that a growing number of studies point to the importance of organizational characteristics in the development of spirit at work (Ashmos and Duchon, 2000; Fairholm, 1997; Jacobson, 1994; Kinjerski and Skrypnek, 2006a; Milliman, et al., 2003; Mitroff and Denton, 1999).

Although a hierarchy of organizational qualities that foster spirit at work is not yet evident, in our research, as in the literature, most factors identified as contributing to spirit at work seem to stem from the leadership within the organization (Secretan, 2004). We would argue that inspired leadership is the key organizational factor that influences all other organizational factors that foster spirit at work.

For example, we found that it was the leaders who set the tone for the organization and inspired the employees by the example they set, thus, maintaining organizational integrity. It was also the leaders who cultivated a shared and compelling vision and promoted alignment between the mission and the organization's work. These are all organizational conditions reported to foster spirit at work, as is a positive workplace culture that promotes a sense of community and shared purpose in the organization. Opportunities for members to pursue professional and personal growth and to fulfill their own personal mission through work, along with appreciation and regard for the contributions made by members, were identified as contributing to one's spirit at work (Kinjerski and Skrypnek, 2006a).

We contend that the primary value of organizational conditions is to foster the integrated personality and facilitate personal actions that foster spirit at work. Whereas the literature points to organizational facets that impede and others that enhance spirit at work, our research showed that individuals who took the contextually sensitive path to spirit at work and, for a time, lost their spirit at work, relied on their personality and personal actions to recreate that experience of spirit at work (Kinjerski and Skrypnek, 2005).

\section{The Paths to Spirit at Work}

Many people in our study described spirit at work as a journey in which personality traits, personal actions, and organizational features interact to foster its development. However, the variation of the four distinct 
paths to spirit at work - always there, coming together, transformative event, and contextually sensitive (Kinjerski and Skrypnek, 2005) - suggests that perhaps these factors weigh differently for persons on the various paths.

For some participants in our research, spirit at work is "always there"- the experience is always present and is sustained over time. The "always there" path suggests that the creation of spirit at work, for some individuals, may be more heavily influenced by personality traits, supporting Emmons' (1999; 2000) notion of spiritual intelligence. Perhaps individuals also have an ability or propensity to experience spirit at work. Persons on the "always there" path seem to enjoy a constant experience of spirit at work in spite of performing work that appears meaningless or working under negative working conditions.

Others describe their experience of spirit at work as a "coming together" of their values, abilities, passions, and life experience. For many of these individuals, spirit at work seems to emerge during mid-life. A personal responsibility to foster spirit at work seems to be fundamental to the "coming together" path. Persons on this path see spirit at work as a journey and something that they constantly work at.

A third way of coming to spirit at work is in response to a "transformative event." The "transformative event" path suggests that anyone, of any personality type or age, can experience a personal transformation that leads to spirit at work. These spiritual transformations, whether as a result of a spiritual crisis or spiritual growth, are integrated into one's work and one's relationship with their work, thus leading to the experience of spirit at work (Mendoza, 1998; Neal, Lichenstein, and Banner, 1999).

Finally, some individuals describe their experience of spirit at work as "contextually sensitive," that is, it is influenced by their contextual environment, thus, waxes and wanes. Whereas organizational factors set the context for all paths, it is evident that persons on the "contextually sensitive" path are more dependent on the conditions of the organization than others. The growing body of research on organizational spirit at work and the findings regarding corporate culture, and leadership in particular, lend support for this path (Milliman, et al., 1999; Neck and Milliman, 1994).

\section{Benefits of Spirit at Work}

Research is demonstrating a positive relationship between the presence of spirit at work and employee wellness as well as organizational performance (Kinjerski and Skrypnek, 2006). Spirit at work is reported to add meaning to one's life, enhance one's creativity, and increase one's commitment to and enthusiasm for work (Fairholm, 1997; Groen, 2003; Milliman et al., 1999; Moxley, 2000). An empirical relationship between spirit at work and job satisfaction (Kinjerski and Skrypnek, 2006; Looney and Brewer, 2003), increased organizational performance including higher profits and success (Mitroff and Denton, 1999), increased organizational commitment (Kinjerski and Skrypnek, 2006), and decreased absenteeism and turnover (Kinjerski and Skrypnek, 2006) is beginning to emerge. Milliman, et al., (2003) have provided empirical support regarding the positive association between spirituality at work, as measured by meaningful work, sense of community, and alignment of values with the organization, and employee job outcomes such as organizational commitment, intention to quit, intrinsic satisfaction with work, and job involvement. In our own research, individuals with high spirit at work have reported that spirit at work has a positive effect on their personal wellbeing, relationships, consumer relations, and productivity. In particular, the results of high levels of spirit at work include: (a) individual wellbeing that overflows to other parts of life; (b) a positive effect on relationships, including a sense of community with those whom one works; (c) improved consumer service; as well as (d) increased productivity in terms of the quality and quantity of work produced (Kinjerski, 2004). Moreover, we found that increasing spirit at work results in reduced absenteeism and turnover and increased job satisfaction and commitment (Kinjerski and Skrypnek, 2006).We call this a "win-win-win" as the desired benefits of the ecological model of spirit at work are positive outcomes for the employee, the consumer, and the organization.

\section{THE EMERGENCE OF A MODEL}

An empirically grounded human ecological model of spirit at work identifying antecedent conditions and outcomes of spirit at work is presented in Figure 1. Four distinct paths to spirit at work - always there, coming together, transformative event, and contextually sensitive - are delineated. These paths are 
influenced by the interaction of individual factors including personality characteristics and the personal actions taken by the individual and contextual factors including organizational conditions and transformative life events. Thus, the underlying principle of this model is:

The interconnection among particular personality characteristics, positive organizational conditions, and personal actions contributes to the creation and enhancement of spirit at work which leads to positive outcomes for employees, consumers, and organizations.

We suggest that it is the organizational characteristics, and the leadership of the organization in particular, that set the context for spirit at work to grow. Given our contention that spirit at work begins with the individual, it is reasonable to expect that employees with well adjusted personality profiles including a spiritual inclination and who practice conscious intention are more likely to experience spirit at work. That may be why these people are able to transcend a negative work environment. The path one takes to spirit at work is influenced by a combination of personality, personal actions, and organizational conditions. As these factors can change, so can one's path to spirit at work. Finally, we put forth that the benefits of spirit at work are directly associated with the level of spirit at work experienced by the employees. There is a direct relationship between spirit at work and these kinds of outcomes.

\section{IMPLICATIONS FOR RESEARCH AND PRACTICE}

Considering how much writing has occurred about spirit at work and the amount of conceptual work that has taken place over the last decade, it is surprising that there is still so little empirical research. We believe that this is due to a lack of psychometrically sound measures and a conceptual framework to guide research.

We offer a human ecological model of spirit at work that, while still in its infancy, may provide a useful framework for stimulating and guiding future research. The model draws heavily on our own research, but is also consistent with the existing body of spirit at work literature. Depicting the antecedents and outcomes of spirit at work, this framework posits that spirit at work is a shared responsibility between the employee and the organization and that it is this interconnection that fosters spirit at work and results in positive outcomes for employees, consumers, and organizations. Moreover, our research indicated that spirit at work develops across all ages, gender, education, occupations, and socio-economic groups (Kinjerski, 2004; Kinjerski and Skrypnek, 2005; 2006b). Thus, it follows that the development of spirit at work could be fostered during anytime over the life span, extending its appeal to individuals and organizations seeking to enhance spirit at work.

The revelation that the creation of spirit at work is a shared responsibility among employees and the organization implies that efforts should be directed at both the individual and workplace. The awareness that spirit at work can be fostered in the workplace and increased spirit at work results in decreased turnover and absenteeism and increased job satisfaction and organizational commitment (Kinjerski and Skrypnek, 2006) makes a strong case for such efforts. This discovery opens the doors for personal exploration and development as well as program development and implementation at the organizational level. For example, strategies designed to enhance individual spirit at work can target the employee, the organization, or both. They can be limited to individual personal growth and transformation or can be as comprehensive as an organizational transformation intervention. It is clear that spirit at work can be

fostered through a multitude of strategies, programs, policies, and training initiatives at the organizational level.

\section{REFERENCES}

Ashmos, D. and Duchon, D. (2000) Spirituality at work, Journal of Management Inquiry, 9, 134-145.

Denzin, N.K. and Lincoln, Y.S. (1998) Introduction, in N.K. Denzin and Y.S. Lincoln (Eds.), Strategies of Qualitative Inquiry. Thousand Oaks, CA: Sage.

Emmons, R.A. (1999) Religion in the psychology of personality: An introduction, Journal of Personality, 67(6), 87388. 
Emmons, R.A. (2000) Is spirituality an intelligence? Motivation, cognition, and the psychology of ultimate concern, The International Journal for the Psychology of Religion, 10, 3-26.

Fairholm, G.W. (1996) Spiritual leadership: Fulfilling whole-self needs at work, Leadership \& Organizational Development Journal, 17(5), 11-17.

George, L.K., Larson, D.B., Koenig, H.G., and McCullough, M.E. (2000) Spirituality and health: What we know, what we need to know, Journal of Social and Clinical Psychology, 19, 102-116.

Groen, J. (2003) How leaders cultivate spirituality in the workplace: What the research shows, Adult Learning, 12, 2021.

Jacobson, S. (1994) Spirituality and Transformational Leadership in Secular Settings: A Delphi Study, An abridgement of an unpublished dissertation. Seattle University.

Kinjerski, V. (2004) The Interconnectedness of Personality, Personal Actions, Organizational Features, and the Paths to Spirit at Work, Unpublished Dissertation, University of Alberta, Edmonton.

Kinjerski, V.M. and Skrypnek, B.J. (2004) Defining spirit at work: Finding common ground, Journal of Organizational Change Management, 17, 26-42.

Kinjerski, V. and Skrypnek, B.J. (2005) The paths to spirit at work, Unpublished manuscript University of Alberta, Edmonton.

Kinjerski, V. and Skrypnek, B.J. (2006) The spirit at work project: Creating positive outcomes in long-term care, $10^{\text {th }}$ Annual Long Term Care Winter Conference, Jasper, Alberta.

Kinjerski, V. and Skrypnek, B.J. (2006a) Creating organizational conditions that foster spirit at work, Leadership and Organization Development Journal, 27, 280-295.

Kinjerski, V. and Skrypnek, B.J. (2006b) Measuring the intangible: Development of the Spirit at Work Scale, in M. Weaver (ed.), Best Paper Proceedings of the Sixty-fifth Annual Meeting of the Academy of Management (CD), ISSN 1543-8643. A1:A6.

Looney, R.A. and Brewer, E.W. (2003) Spirituality in the nursing workplace, in G. Biberman, and A. Alkhafaji, (Eds.), Business Research Yearbook: Global Business Perspectives, Vol. X. Saline, MI: Publication of the International Academy of Business Disciplines. 1028-1032.

McCrae, R.R., and Costa, P.T. (1999) A five-factor theory of personality, in L.A. Pervin, and O.P. John, (Eds.), Handbook of Personality: Theory and Research (2nd ed.), New York: Guilford. 139-153.

Mendoza, R.H. (1998) The Touch of a Leader's Soul: How a Leader Brings Soul to an Organization, Unpublished Dissertation, University of Sarasota, Florida.

Milliman, J., Czaplewski, A.J., and Ferguson, J. (2003) Workplace spirituality and employee work attitudes: An exploratory empirical assessment, Journal of Organizational Change Management, 16, 426-447.

Milliman, J., Ferguson, J., Trickett, D., and Condemi, B. (1999) Spirit and community at Southwest Airlines: An investigation of a spiritual values-based model, Journal of Organizational Change Management, 12, 221233.

Mitroff, I. and Denton, E. (1999) A study of spirituality in the workplace, Sloan Management Review, 40(4), 83-92.

Moxley, R. (2000) Leadership and Spirit: Breathing new Vitality and Energy into Individuals and Organizations. San Francisco: Jossey-Bass.

Neal, J.A., Lichenstein, B.M.B. and Banner, D. (1999) Spiritual perspectives on individual, organizational and societal transformation, Journal of Organizational Change Management, 12, 175-185.

Neck, C. and Milliman, J. (1994) Thought self-leadership: finding spiritual fulfillment in organizational life, Journal of Managerial Psychology, 9(6), 9-16.

Paloutzian, R.F., Emmons, R.A. and Keortge, S.G. (2003) Spiritual well-being, spiritual intelligence, and healthy workplace policy, in R.A. Giacalone and C.L. Jurkiewicz, (Eds.), Handbook of Workplace Spirituality and Organizational Performance. Armonk, New York: M.E. Sharpe.

Piedmont, R.L. (1999) Does spirituality represent the sixth factor of personality? Spiritual transcendence and the five factor model, Journal of Personality, 67, 985-1013.

Piedmont, R.L. (2001) Spiritual transcendence and the scientific study of spirituality, Journal of Rehabilitation, 67, 414.

Secretan, L. (2004) Inspire! What Great Leaders Do, Hoboken, New Jersey: John Wiley \& Sons.

Sheep, M.L. (2004) Nailing down gossamer: A valid measure of the person-organization fit of workplace spirituality, Best Paper Proceedings of the Sixty-Third Annual Meeting of the Academy of Management, B1-B6. 